\title{
Silage quality of Brachiaria brizantha cultivars ensiled with different levels of millet meal
}

\author{
[Qualidade de silagem de cultivares de Brachiaria brizantha ensilado com diferentes níveis \\ de farelo de milheto] \\ K.A.P. Costa $^{1}$, R.L. Assis ${ }^{1}$, K.C. Guimarães ${ }^{2}$, E.C. Severiano ${ }^{2}$, J.M. Assis Neto ${ }^{3}$, \\ W.S. Crunivel ${ }^{4}$, J.F. Garcia ${ }^{4}$, N.F. Santos ${ }^{5}$ \\ ${ }^{1}$ Instituto Federal Goiano - Campus Iporá \\ Rodovia GO 060, Km 01 - Zona Rural \\ 76200-000 - Iporá, GO, \\ ${ }^{2}$ Instituto Federal Goiano - Campus Rio Verde \\ ${ }^{3}$ Zootecnista - Fazenda Reunidas Boi Gordo \\ ${ }^{4}$ Alunos de graduação - Fesurv - Universidade de Rio Verde \\ ${ }^{5}$ Aluna de graduação - Instituto Goiano Federal - Campus Rio Verde
}

\begin{abstract}
The silage quality of Brachiaria brizantha cultivars ensiled with different levels of millet meal was evaluated. The experimental design was a completely randomized with three replications in a factorial $3 \mathrm{x}$ 4, with three cultivars of Brachiaria brizantha: marandu, xaraés, and piatã and four levels of millet meal $0,5,10$, and $15 \%$. The addition of millet meal improved the quality of $B$. brizantha silage. The inclusion of the additive at $15 \%$ provided the best nutritional values. The piatã silage had the lowest contents of neutral detergent fiber, acid detergent fiber, and lignin and the highest content of total digestible nutrients, being a better quality silage as compared to those of xaraés and marandu grasses.
\end{abstract}

Keywords: millet meal, marandu grass, piatã grass, xaraés grass

\section{RESUMO}

Avaliou-se a qualidade de silagem de cultivares de Brachiaria brizantha ensilados com diferentes níveis de farelo de milheto. O delineamento experimental utilizado foi inteiramente ao acaso, com três repetições, em esquema fatorial $3 \times 4$, sendo, três cultivares de Brachiaria brizantha: marandu, xaraés e piatã e quatro níveis de farelo de milheto: 0, 5, 10 e 15\%. A adição de farelo de milheto melhorou a qualidade das silagens de cultivares de B. brizantha. A inclusão de $15 \%$ do aditivo proporcionou os melhores valores nutritivos. A silagem de capim-piatã apresentou os menores teores de fibra em detergente neutro, de fibra em detergente ácido e de lignina, e o maior teor de nutrientes digestíveis totais, mostrando ser de melhor qualidade quando comparada com as silagens de capim-xaraés e capimmarandu.

Palavras-chave: farelo de milheto, capim-marandu, capim-xaraés, capim-piatã

\section{INTRODUCTION}

For the sustainability of production systems with high yield of plant and animal components and, above all, respecting the morphological and structural limits of grazing, new cultivars are developed to meet the requirements of different production systems, with varying levels of technology. Thus, the Embrapa Gado de Corte has developed Brachiaria brizantha cv. Xaraés in 2003 and recently B. brizantha BRS, Piatã, as another option in the forage diversification. The researchers concluded that these grasses have excellent performance in soils of average fertility, have a high regrowth rate, and stand out for high forage production and nutritive value

Recebido em 15 de dezembro de 2009

Aceito em 10 de dezembro de 2010

E-mail: katiazoo@hotmail.com 
(Embrapa..., 2007). These forages, besides being used for grazing, have also nutritional characteristics suitable for ensilage process.

The tropical grass silage is recommended as an alternative to increasing the forage supply during the dry season. One of the most viable strategies is the ensilage of the surplus produced in the rainy season, because in addition to providing forage for the dry season, it also allows to rationalize the intensive management of pastures during the rainy season. However, high humidity and low carbohydrate levels at the cutting time of tropical grasses are factors that inhibit the proper fermentation process, preventing the production of good quality silage. These factors negatively affect the fermentation process, preventing the rapid $\mathrm{pH}$ decrease to proper levels and thus allowing undesirable secondary fermentations (Evangelista et al., 2004).

Alternatives to increase dry matter percentage and soluble carbohydrates in the material to be ensiled have been widely studied by the use of additives, which provide better quality silage (Pazian et al., 2006a). The millet grain, due to its high nutritional value (Benedetti, 2009), can be used as an alternative of additive for tropical grass silage. Thus, the determination of nutritional characteristics of the millet grain is very important because they generate information on the nutritional value of the food. So, this study was carried out to evaluate the silage quality of three cultivars of $B$. brizantha ensiled with different levels of millet meal.

\section{MATERIAL AND METHODS}

The experiment was carried out with forages established in November 2008 in an area of approximately $500 \mathrm{~m}^{2}$. The soil was classified as distroferric Red Latosol (Embrapa..., 2006), with $580 \mathrm{~g} \mathrm{~kg}^{-1}$ clay, $50 \mathrm{~g} \mathrm{~kg}^{-1}$ silt, and $370 \mathrm{~g} \mathrm{~kg}^{-1}$ sand. The chemical characteristics of soil at $0-20 \mathrm{~cm}$ of depth before planting were: $\mathrm{pH}\left(\mathrm{CaCl}_{2}\right): 5.1$, Ca: $2.89 \mathrm{cmol}_{\mathrm{c}} \mathrm{dm}^{-3}$; $\mathrm{Mg}: 1.47 \mathrm{cmol}_{\mathrm{C}} \mathrm{dm}^{-3} ; \mathrm{Al}$ : $0.01 \mathrm{cmol}_{\mathrm{c}} \mathrm{dm}^{-3} ; \mathrm{Al}+\mathrm{H}: \quad 3.5 \mathrm{cmol}_{\mathrm{c}} \mathrm{dm}^{-3} ; \mathrm{K}:$ $0.24 \mathrm{cmol}_{\mathrm{C}} \mathrm{dm}^{-3}$; CTC: $8.0 \mathrm{cmol}_{\mathrm{C}} \mathrm{dm}^{-3}$; P: $5.54 \mathrm{mg}$ $\mathrm{dm}^{-3} ; \mathrm{SO}_{4}^{-2}$ : $8.6 \mathrm{mg} \mathrm{dm}^{-3}$; $\mathrm{Cu}: 3.8 \mathrm{mg} \mathrm{dm}^{-3}$; Zn: $3.5 \mathrm{mg} \mathrm{dm}^{-3}$; Fe: $29 \mathrm{mg} \mathrm{dm}^{-3}$; Mn: $53.8 \mathrm{mg} \mathrm{dm}^{-3}$; V: $55.6 \%$; and M.O: $27.7 \mathrm{~g} \mathrm{dm}^{-3}$.

The area preparation was done by eliminating invasive plants, applying $3 \mathrm{~L} \mathrm{ha}{ }^{-1}$ of glyphosate.
Fifteen days after desiccation, the harrowing was performed, followed by leveling. It was applied at planting $80 \mathrm{~kg} \mathrm{ha}^{-1} \quad \mathrm{P}_{2} \mathrm{O}_{5}$, using the superphosphate. The forage planting was made by throwing, using $9 \mathrm{~kg}$ per hectare of pure viable seeds of $B$. brizantha cV. Marandu, Xaraés, and Piatã. Nitrogen $\left(200 \mathrm{~kg} \mathrm{ha}^{-1} \mathrm{~N}\right)$ and potassium (60kg ha ${ }^{-1}$ of $\mathrm{K}_{2} \mathrm{O}$ ) fertilization were performed 45 days after planting, topdressing, using sources such as ammonium sulfate and potassium chloride, respectively. Nitrogen was split in three phases after each forage cutting. The applications were made in January, February, and March. They were done to forage cuts before the cutting for silage process.

The experimental design was a completely randomized with three replications in a factorial $3 \times 4$, with three $B$. brizantha cultivars marandu, xaraés, and piatã and four levels of millet meal $-0,5,10$, and $15 \%$, obtained on grass dry matter basis. The millet meal was ADR 500 cultivar, obtained by grains milling.

For the ensiling process, forages were harvested in April 2009, at the growth stage of 40 days, cut at $20 \mathrm{~cm}$ from the soil, using a brushcutter. Subsequently, the forages were chopped into stationary chopper in particles of 10 to $30 \mathrm{~mm}$. Then, the chopped material was mixed with millet meal at rates determined and stored in PVC silos, measuring $10 \mathrm{~cm}$ diameter and $40 \mathrm{~cm}$ length. The ensiled material was packed with iron pendulum and the silos were sealed with PVC caps, fitted with Bunsen valves, and sealed with tape. Once closed, the silos were placed in a tilted position, to facilitate the exit of effluents by Bunsen valve, simulating a trench silo.

After 60 days of fermentation, the silos were opened, discarding the top and bottom portions of each one. The central portion of the silo was homogenized and placed in plastic trays. After opening, the $\mathrm{pH}$ was analyzed using the phmeter Expandomatic Beckman SS-2. Subsequently, the material was weighed and taken to a forced air oven $60-65^{\circ} \mathrm{C}$ for 96 hours for determination of pre-dried matter. The samples were ground in a Willey-type mill with a mesh sieve of $1 \mathrm{~mm}$ for analysis.

The chemical analyses were performed to determine the levels of dry matter (DM), crude protein (CP), neutral detergent fiber (NDF), acid 
detergent fiber (ADF), and lignin (On), as described by Silva and Queiroz (2002). The total digestible nutrient (TDN) was obtained by the NDF content using the equations proposed by
Chandler (1990). The results of chemical analyses of forages and millet meal before ensiling are shown in Table 1.

Table 1. Dry matter (DM), crude protein (CP), neutral detergent fiber (NDF), acid detergent fiber (ADF), lignin (Lig), and total digestible nutrients (TDN) of marandu, xaraés and piatã grasses and millet meal used in the production of silage

\begin{tabular}{lcccc}
\hline \multirow{2}{*}{ Variable } & \multicolumn{4}{c}{ Brachiaria brizantha cultivars } \\
\cline { 2 - 5 } DM (\%) & marandu grass & xaraés grass & piatã grass & Millet meal \\
CP (\%) & 18.8 & 19.2 & 18.4 & 93.5 \\
NDF (\%) & 12.8 & 13.4 & 13.9 & 16.2 \\
ADF (\%) & 68.4 & 70.1 & 67.3 & 21.8 \\
Lig. (\%) & 39.6 & 40.2 & 37.2 & 9.6 \\
TDN (\%) & 4.5 & 4.8 & 4.3 & 2.8 \\
\hline
\end{tabular}

The data were submitted to analyses of variance and of regression, and means were compared by Tukey test at $5 \%$ of probability using the statistical program SISVAR 4.6.

\section{RESULTS AND DISCUSSION}

The DM values were not affected $(\mathrm{P}>0.05)$ by cultivar (Table 2) and no effect $(\mathrm{P}<0.05)$ of millet meal levels and interaction of cultivars versus millet meal levels (Figure 1a) were observed on DM values.

The increase in DM of silage for all cultivars was linear (Figure 1a) with increasing levels of millet meal. The addition of $15 \%$ of millet meal as an additive was enough to raise the dry matter from 20.5 to $28.4 \%$, $21.9 \%$ to 31.5 , and 19.7 to $31.0 \%$ for marandu, piatã, and xaraés silages, respectively. This shows that millet is efficient in absorbing water into the silo, thereby facilitating the fermentation process. Paziani et al. (2006a) working with tanzania grass ensiled with millet, found that the millet was effective in increase the DM content of silage from 20.1 to $28.8 \%$. Muck and Shinners $(2001)$ reported that if DM content is less than $30 \%$, increase in losses may occur in the form of effluent and a higher probability of fermentation by clostridiums, resulting in food of low acceptability.

No effect of cultivar $(\mathrm{P}>0.05)$ was verified on $\mathrm{CP}$ (Table 2) and it was observed an influence $(\mathrm{P}<0.05)$ of the millet meal levels and interaction of cultivar versus millet meal levels (Figure 1b) on CP.

Table 2. Dry matter (DM), crude protein (CP), neutral detergent fiber (NDF), acid detergent fiber (ADF), lignin (Lig), total digestible nutrients (TDN), and pH of of Marandu, Xaraés, and piatã silages

\begin{tabular}{lcccc}
\hline \multirow{2}{*}{ Variable } & \multicolumn{4}{c}{ Brachiaria brizantha cultivars } \\
\cline { 2 - 5 } & marandu grass & xaraés grass & piatã grass & CV $(\%)$ \\
\hline DM (\%) & $25.42 \mathrm{a}$ & $25.25 \mathrm{a}$ & $26.55 \mathrm{a}$ & 4.92 \\
CP (\%) & $9.12 \mathrm{a}$ & $9.24 \mathrm{a}$ & $9.78 \mathrm{a}$ & 7.07 \\
NDF (\%) & $68.66 \mathrm{~b}$ & $67.75 \mathrm{~b}$ & $63.25 \mathrm{a}$ & 5.59 \\
ADF (\%) & $40.00 \mathrm{a}$ & $42.58 \mathrm{~b}$ & $40.58 \mathrm{a}$ & 3.79 \\
Lig. (\%) & $4.79 \mathrm{a}$ & $4.70 \mathrm{a}$ & $4.30 \mathrm{~b}$ & 8.55 \\
TDN (\%) & $58.50 \mathrm{~b}$ & $59.13 \mathrm{~b}$ & $62.19 \mathrm{a}$ & 4.52 \\
pH & $4.44 \mathrm{a}$ & $4.30 \mathrm{~b}$ & $4.30 \mathrm{~b}$ & 2.39 \\
\hline
\end{tabular}

Means followed by different letters on the row differ by the Tukey test $(\mathrm{P}<0.05)$.

For all cultivars, there was a linearly increase of $\mathrm{CP}$, with increasing levels of millet meal (Figure 1b). The addition of $15 \%$ resulted in $\mathrm{CP}$ contents of $14.4,12.9$, and $10.8 \%$, showing increase of
65,92 , and $52 \%$ relative to non-addition of millet meal, for marandu, xaraés, and piatã silages, respectively. This can be explained by two reasons: the millet contains high levels of $\mathrm{CP}$ in 
the grain, thus improving the quality of forage silage; and the higher dry matter content in the bran meal could restrict the Clostridium activity (Aguiar et al., 2001), preserving the protein

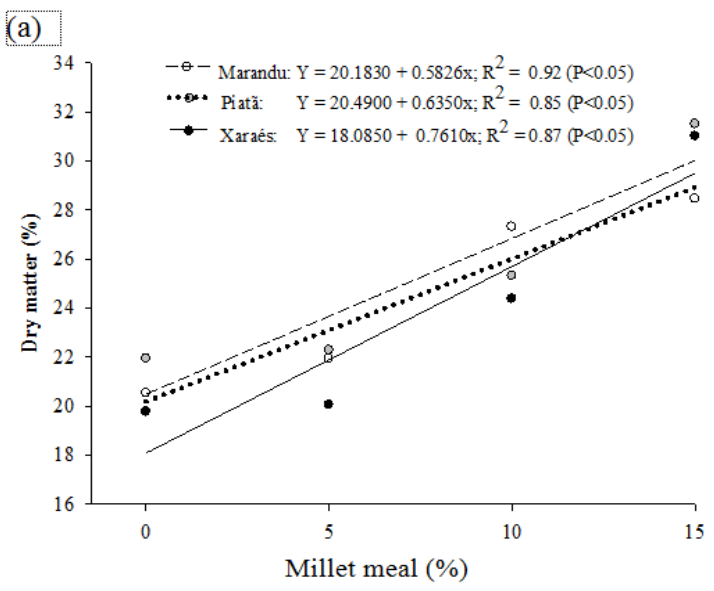

Figure 1. Content of dry matter (a) and crude protein (b) of silages of Brachiaria brizantha cultivars ensiled with different levels of millet meal.

The use of additives in silages of tropical forages is important because they reduce the risks of the ensiling process and improve the nutritive value of silage. According to Zanine et al. (2006), a good additive for ensiling tropical grasses should have high dry matter content, excellent water absorption capacity, high nutritional value, good palatability, and high content of soluble carbohydrates, and also need to be easily manipulated, available at market, and be of low cost. Millet presented important qualitative characteristics, such as high DM content, CP, and TDN and low NDF, ADF and lignin (Table 1). Guimarães Jr. et al. (2008) reported that although the energy content of pearl millet grain is lower than the maize and sorghum, it has high protein content, which justify its use as an option for the ensiling process.

The piatã grass silage with the addition of $15 \%$ of millet meal had the highest content of CP, showing increases of 13 and 19\% compared to silages of marandu and xaraés grasses, respectively (Figure $1 \mathrm{~b}$ ). This highest content of CP obtained in piatã grass silage can be explained by the plant morphology, which has thin stems (4mm diameter) and, therefore, produces better quality forage due to high leaf:stem ratio (Embrapa..., 2007). fraction of forage. Similar results were observed by Pazian et al. (2006b), that reported $11.4 \%$ of crude protein in tanzania grass silage with the addition of millet meal.

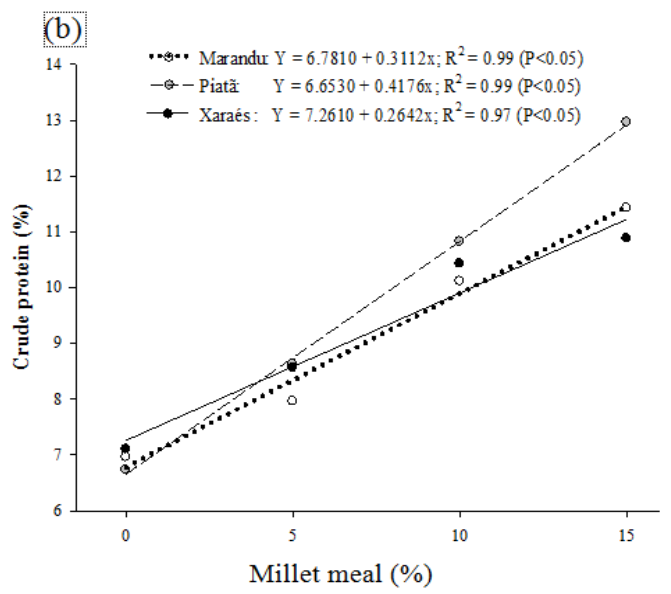

The NDF content was influenced $(\mathrm{P}<0.05)$ by cultivar (Table 2) and by the levels of millet meal (Figure 2). However, the effect of interaction of cultivar versus millet meal levels not significant.

The lowest NDF content was obtained in the piatã grass silage. It was different from those of xaraés and marandu grasses silages, which showed similar levels (Table 2). Van Soest (1994) reported that the NDF values are negatively correlated with intake, which suggests that the piatã grass silage may offer better terms of consumption than the others.

As there was an increase in the addition of millet meal in the ensilage process, there was a linear decrease in NDF content, regardless of the studied cultivars (Figure 2). The addition of $15 \%$ helped to reduce by $14 \%$ the NDF content compared to non-application of this additive. This decrease is probably due to the low NDF content present in the millet meal (21.8\%), and as there was a replacement as part of a millet meal in the grass silage, the dilution effect of fiber was observed. The reduction in NDF content of elephant grass silage, by the addition of wheat meal was also found by Ribeiro et al. (2008) 


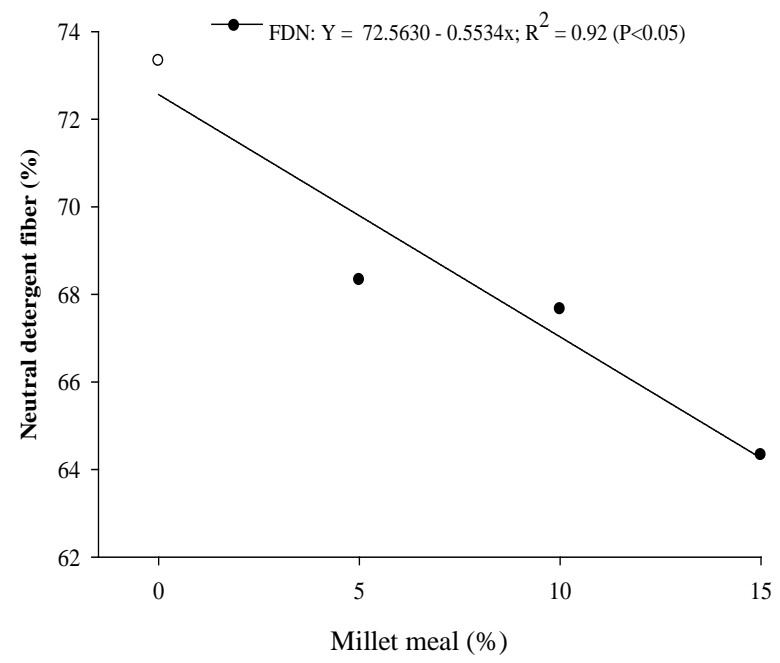

Figure 2. Content of neutral detergent fiber (FDN) of silages with different levels of millet meal.

As for the ADF, there was a significant difference $(\mathrm{P}<0.05)$ between cultivars (Table 2$)$, and for the interaction of cultivar and millet meal levels (Figure 3a).

Piatã and marandu silages had the lowest levels of ADF, differing from xaraés grass silage (Table 2). According to Van Soest (1994), ADF is negatively correlated with forage digestibility, which favors the marandu and piatã silages, by presenting the lowest levels of the ADF

For all cultivars of $B$. brizantha, there was a linear reduction on the ADF, with increased levels of millet meal (Figure 3a). This decrease is attributed to the dilution effect, since the millet meal has low ADF value (9.6\%) compared to $B$. brizantha. Another fact that should be taken into consideration is that the millet meal addition promoted an increase in dry matter (Figure 1a), and it probably favored a better fermentation of the ensiled material, and reduced losses caused by the formation of effluents according to Ribeiro et al. (2008).

The ADF values obtained in this study are above those found by Paziani et al. (2006b), of 31.5\% when added millet meal in tanzania grass silage. In a study of wheat meal inclusion in tanzania grass silage, Ribeiro et al. (2008) found that the addition of $34 \%$ of wheat meal reduced ADF from $46.8 \%$ to $22.7 \%$, improving the quality of silage.
Lignin content were influenced $(\mathrm{P}<0.05)$ by $B$. brizantha cultivar, by millet meal levels, and by the interaction of these factors. The piatã grass silage showed lignin content significantly lower than the marandu and xaraés silages (Table 2). This result is due to greater leaf:stem ratio of Piatã, as was explained by Embrapa... (2007).

There was a quadratic decrease in lignin content for all $B$. brizantha cultivars, with the increase in the levels of millet meal (Figure 3b). The levels obtained with $15 \%$ of inclusion were 3.7, 3.3, and $4.2 \%$, showing a reduction compared to no addition of millet meal of 38, 45, and $19 \%$ for the silages of marandu, xaraés, and piatã grasses, respectively.

Lignin is associated with food indigestibility, but, more important than its content it is its structural arrangement in the cell wall of forage (Jung and Deetz, 1993). However, it has been approached the lignin content in tropical grasses as depreciative fraction of food (Leonel et al., 2009).

In a study on tanzania grass ensiled with wheat meal, Ribeiro et al. (2008) found that the fractions of cellulose, hemicellulose, and lignin decreased with the inclusion of wheat meal, demonstrating that the addition of this additive became the silage more digestible. This fact can be explained by decay power of lignin, which is softened and allows better use of the fiber by microorganisms. 

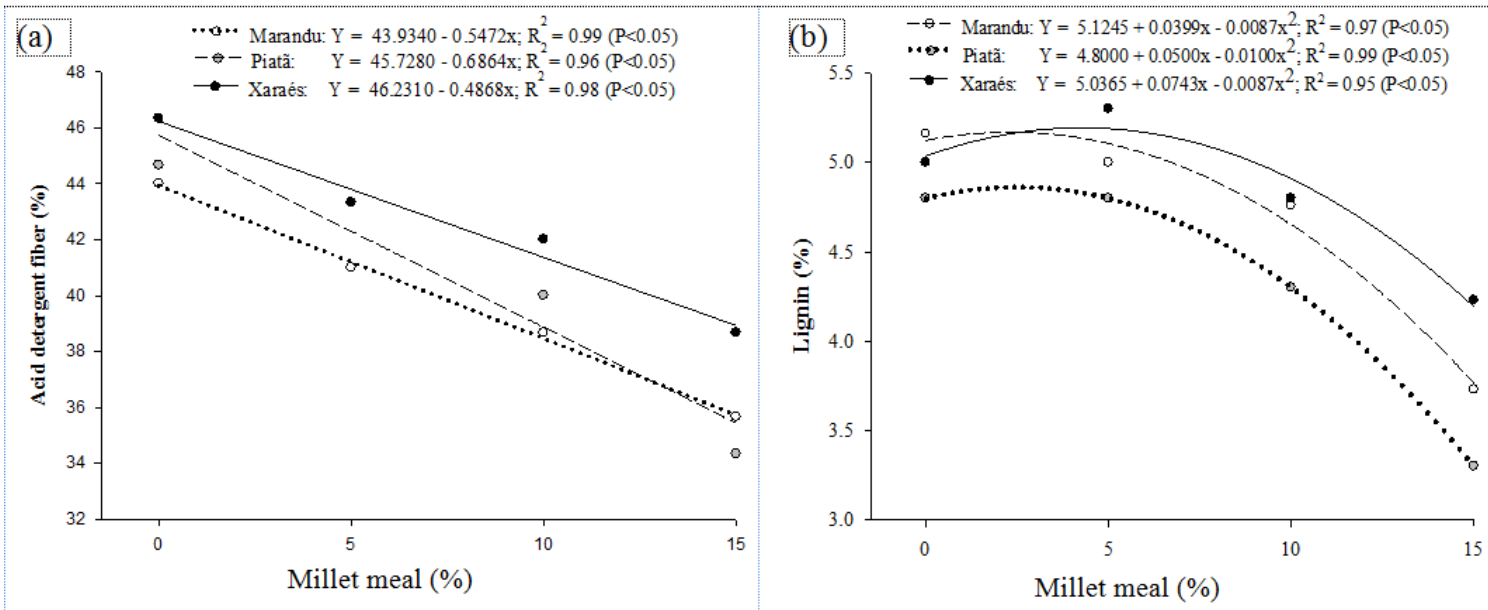

Figure 3. Content of acid detergent fiber (ADF) (a) and lignin (b) in Brachiaria brizantha silages with different levels of millet meal.

There was a linear increase in TDN content as it was increased the inclusion levels of millet meal (Figure $4 a$ ). The addition of $15 \%$ of millet meal increased by $11 \%$ the TDN content when compared with no application of this additive on silage fermentation. In a study on qualitative and

nutritional characteristics of Brachiaria grass silage, Leonel et al. (2009) found TDN content of 50.3\%, and Silva et al. (2005) and Chizzotti et al. (2005) found 51.5 and $48.8 \%$, respectively, in B. brizantha cv. Marandu silage.

(a)
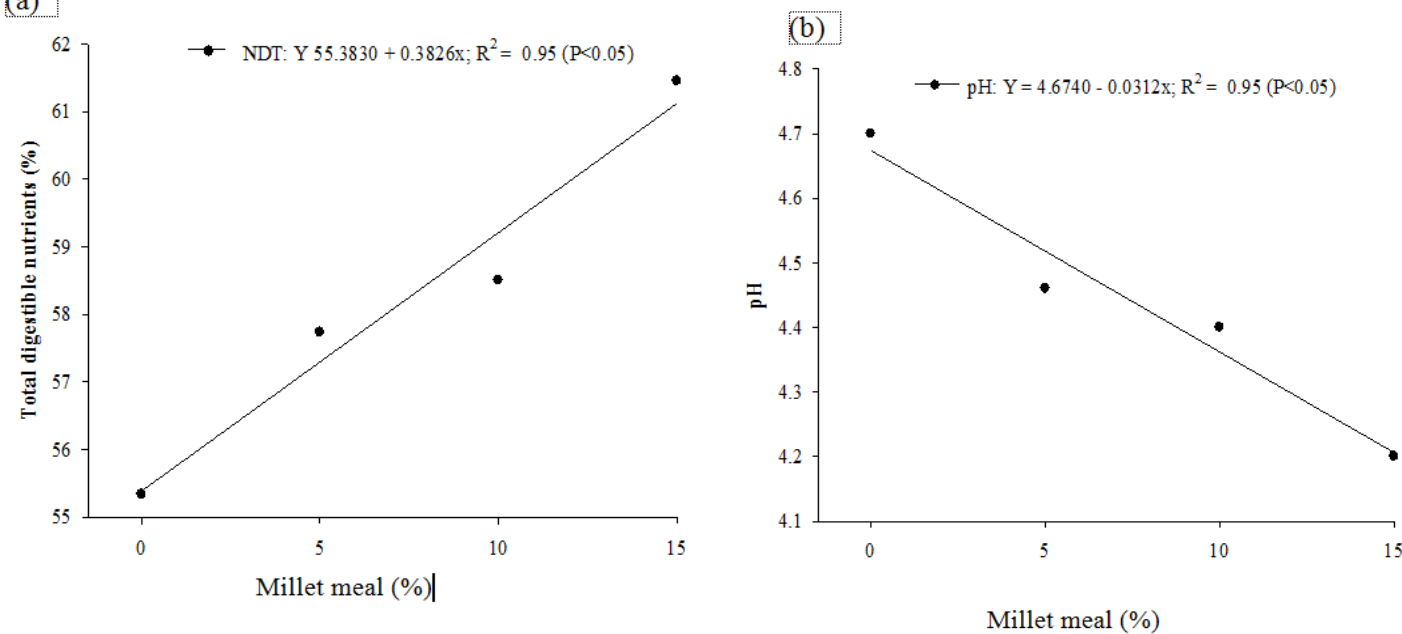

Figure 4. Content of total digestible nutrients (NDT) (a) and pH (b) of silages with different levels of millet meal.

The $\mathrm{pH}$ of silages was not affected $(\mathrm{P}>0.05)$ by the interaction of cultivars and levels. There was a significant effect of cultivar (Table 2) and levels of millet meal inclusion (Figure 4b). Among the silages, the marandu grass one

showed higher $\mathrm{pH}$, differing $(\mathrm{P}<0.05)$ from piatã and xaraés silages (Table 2).

There was a linear decrease in $\mathrm{pH}$ value, as it was increased the inclusion levels of millet meal during the ensilage (Figure 4b). The addition of 
$15 \%$ of millet meal reduced the $\mathrm{pH}$ by 0.5 unit, compared to the treatment that did not receive the additive. The highest $\mathrm{pH}$ value in silages without the addition of millet meal is due to the lowest content of soluble carbohydrates in plants of the Brachiaria genus. These results show the effectiveness of millet meal in lowering the $\mathrm{pH}$ of silages, which contain high levels of DM (Table 1). These $\mathrm{pH}$ values are below 4.7 obtained by Paziani et al. (2006a), when added millet meal in tanzania grass ensilage process.

Galan and Nussio (2000) reported that high humidity and low soluble carbohydrate at the cut time of tropical grasses are factors that inhibit the proper fermentation process, hampering the production of silage with good quality. These factors affect negatively the fermentation process, preventing the rapid decrease in $\mathrm{pH}$ to adequate levels (3.8 to 4.2) and allowing undesirable secondary fermentations (Jayme et al., 2009). Thus, the final $\mathrm{pH}$ of silage is an indicative of the quality of fermentation process and its value inside the silo must become, as quickly as possible, low enough to inhibit the growth of undesirable bacteria, such as those of the Clostridium genus (McDonald et al., 1991)

\section{CONCLUSIONS}

The addition of millet meal improved the silage quality of $B$. brizantha cultivars. The inclusion of $15 \%$ of this additive in silage provided the best nutritional values. The piatã grass silage had the lowest contents of NDF, ADF, lignin and the highest content of TDN, showing to have better quality when compared with xaraés and marandu grass silages.

\section{REFERENCES}

AGUIAR, R.N.S.; CRESTANA, R.F.; BALSALOBRE, M.A.A. Efeito do tamanho de partícula na composição da fração nitrogenada de silagem de capim Tanzânia. In: REUNIÃO ANUAL DA SOCIEDADE BRASILEIRA DE ZOOTECNIA, 38., Piracicaba, 2001. Anais... Piracicaba: FEALQ, 2001. p.314-316.

BENEDETTI, E. Milheto na alimentação de ruminantes. Rev. Agronegócio, n.27, p.34-36, 2009.
CHANDLER, P. Energy prediction of feeds by forage testing explorer. Feedstuffs, v.62, p.12, 1990.

CHIZZOTTI, F.H.M.; PEREIRA, O.G.; VALADARES FILHO, S.C. et al. Consumo, digestibilidade total e desempenho de novilhos nelore recebendo dietas contendo diferentes proporções de silagens de Brachiaria brizantha cv. Marandu e de sorgo. Rev. Bras. Zootec., v.34, supl., p.2427-2436, 2005.

EMBRAPA GADO DE CORTE. Piatã é o novo capim lançado pela Embrapa, 2007. Available In: $<$ http://www.cnpgc.embrapa.br/index.php?pagina= produtoseservicos/produtos.html/> . Accessed: Nov, 152009.

EMPRESA BRASILEIRA DE PESQUISA AGROPECUÁRIA. Centro Nacional de Pesquisa de Solos. Ministério da Agricultura, Pecuária e Abastecimento. Sistema Brasileiro de Classificação de Solos. 2.ed. Brasília, DF: Embrapa Informação Tecnológica, 2006. 306p.

EVANGELISTA, A.R.; ABREU, J.G.; AMARAL, P.N.C. et al. Produção de silagem de capimmarandu (Brachiaria brizantha stapf cv. Marandu) com e sem emurchecimento. Cienc. Agrotec., v.28, p.443-449, 2004.

GALAN, V.B.; NUSSIO, L.G. Alimentos volumosos para o inverno: opções para viabilizar a produção de leite. In: SIMPÓSIO DE FORRAGICULTURA E PASTAGENS, 1., 2000, Lavras. Anais... Lavras: UFLA, 2000. p.357-369.

GUIMARAES JÚNIOR, R.; GONÇALVES, L.C.; MAURÍCIO, R.M. et al. Cinética de fermentação ruminal de silagens de milheto. Arq. Bras. Med. Vet. Zootec., v.60, p.1174-1180, 2008.

JAYME, C.G.; MOLINA, L.R.; GONÇALVES, L.C. et al. Determinação do momento de colheita da Brachiaria brizantha (hochest.) stapf. cv. Marandu para produção de silagem. Cienc. Agrotec., v.33, p.586-591, 2009.

JUNG, H.G.; DEETZ, D.A. Cell wall lignification and degradability. In: JUNG, H.G.; BUXTON, D.R.; HATFIELD, R.D. et al. (Eds). Forage cell wall structure and digestibility. Madison: ASA/CSSA/SSSA, 1993. p.315-346.

LEONEL, F.P.L.; PEREIRA, J.C.; COSTA, M.G. et al. Consórcio capim-braquiária e milho: comportamento produtivo das culturas e características nutricionais e qualitativas das silagens. Rev. Bras. Zootec., v.38, p.166-176, 2009. 
McDONALD, P.; HENDERSON, A.R.; HERON, S.J.E. The biochemistry of silage. 2.ed. Bucks: Chalcombe, 1991. 340p.

MUCK, R.E.; SHINNERS, K.J. Conserved forage (silage an hay): progress an priorities. In: INTERNATIONAL GRASSLAND CONGRESS, 19., São Pedro, 2001. Proceedings... Piracicaba: FEALQ, 2001. p.753.

PAZIANI, S.F.; NUSSIO, L.G.; LOURES, D.R.S. et al. Influência do teor de matéria seca e do inoculante bacteriano nas características físicas e químicas da silagem de capim-tanzânia. Acta Scient., v.28, p.265-271, 2006a.

PAZIANI, S.F.; NUSSIO, L.G.; PIRES, A.V. et al. Efeito do emurchecimento e do inoculante bacteriano sobre a qualidade da silagem de capimtanzânia e o desempenho de novilhas. Acta Scient., v.28, p.393-400, 2006b.

RIBEIRO, X.R.R.; OLIVEIRA, R.L.; BAGALDO, A.R. Capim-tanzânia ensilado com níveis de farelo de trigo. Rev. Bras. Saúde Prod. Anim., v. 9, p.631640, 2008.

SILVA, D.J.; QUEIROZ, A.C. Análise de alimentos: métodos químicos e biológicos. 3.ed. Viçosa: UFV, 2002. 235p.

SILVA, B.C.; PEREIRA, O.G.; PEREIRA, D.H. et al. Consumo e digestibilidade aparente total dos nutrientes e ganho de peso de bovinos de corte alimentados com silagem de Brachiaria brizantha e concentrado em diferentes proporções. Rev. Bras. Zootec., v.34, p.1060-1069, 2005.

VAN SOEST, P.J. Nutritional ecology of the ruminant. 2.ed. Ithaca: Cornell University, 1994. 476p.

ZANINE, A.M.; SANTOS, E.D.; FERREIRA, D.J. et al. Efeito do farelo de trigo sobre as perdas, recuperação da matéria seca e composição bromatológica da silagem de capim-mombaça. Braz. J. Vet. Res. Anim. Sci., v.53, p.803-809, 2006. 